\title{
First record of Leptoxyphium madagascariense (Dothideomycetes, Capnodiales) from sugarcane juice
}

\author{
Abdel-Sater $\mathbf{M A}^{1,2}$, Moubasher $\mathbf{A H}^{1,2^{*}}$ \& Soliman $\mathbf{Z}^{2}$ \\ ${ }^{1}$ Department of Botany and Microbiology, Faculty of Science, Assiut University, P.O. Box 71526, Assiut, Egypt \\ ${ }^{2}$ Assiut University Mycological Center, Assiut University, P.O. Box 71526, Assiut, Egypt
}

Abdel-Sater MA, Moubasher AH, Soliman Z 2018 - First record of Leptoxyphium madagascariense (Dothideomycetes, Capnodiales) from sugarcane juice. Plant Pathology \& Quarantine 8(1), 15-22, Doi 10.5943/ppq/8/1/3

\begin{abstract}
During surveys of mycobiota of fresh juices in Assiut area, Egypt, a synnematous dark fungus was isolated from sugarcane juice on malt extract yeast extract 50\% glucose agar, MY50G. Critical phenotypic and ITS sequencing revealed its relatedness to Leptoxyphium madagascariense (99.42\% sequence similarity with Genbank accession nos. NR_137731 \& GQ303277 of the type strain CBS124766 ${ }^{\mathrm{T}}$ ). The strain was deposited at Assiut University Mycological Centre and its ITS sequence was deposited at the National Centre for Biotechnology Information, NCBI. This species is recorded for only the second time after its original description from trees in a tropical rain forest of Madagascar.
\end{abstract}

Key words - Egypt - ITS sequencing - phenotypic features - sooty moulds - synnemata

\section{Introduction}

The family Capnodiaceae was introduced by Höhnel (1910) with the generic type Capnodium Montagne (1849) and presently includes 14 genera and 117 species (Kirk et al. 2008, Lumbsch \& Huhndorf 2010). Capnodiaceae are sooty moulds with bitunicate asci borne in ostiolate ascomata; the family however is based mostly on ecological characters (von Arx \& Müller 1975). The first complete monographic review of capnodiaceous sooty moulds recognized both sexual and asexual species in Eucapnodiaceae (Fraser 1935). Batista \& Ciferri (1963a, b) later provided a monograph of Capnodiaceae in the order Capnodiales. Hughes (1972) reviewed and re-classified Capnodiaceae, which is characterized by the structure of the hyphae, presence or absence of pseudoparaphyses and by deviating conidial states. Members of this family also have superficial ascomata with ovoid asci in fascicles and hyaline to dark, one to multiseptate ascospores (Hughes 1976), superficial mycelium of interwoven, mucilaginous, brown, cylindrical or tape ring hyphae, mostly constricted at the septa, and occur as leaf epiphytes associated with the honeydew of insects (Hughes 1976, Blakeman \& Fokkema 1982, Andrews 1992). These fungi tend to live in complex communities, often with multiple fungal parasites (Faull et al. 2002, Hughes 2003). They produce darkly pigmented hyphae, often of very characteristic morphology (Hughes 1976, Reynolds 1998). Asexual state reported in Capnodiaceae are Acanthorus, Apiosporium, Conidiocarpus, 
Conidioxyphium, Fumagospora, Fumiglobus, Leptoxyphium, Mycogelidium, Phaeoxyphiella, Polychaetella, Polychaeton, Scolecoxyphium, and Tripospermum (Hyde et al. 2011).

Members of Capnodiaceae and Chaetothyriaceae are referred to as sooty moulds since they share the same ecological niche and are similar in appearance. The main distinguishing features between these two families are found in the ascomata having single locules in Capnodiaceae, and ascostromata, often with more than one locule in Chaetothyriaceae. In addition, the ascomata on leaf surfaces are subglobose to globose, with or without setae in Capnodiaceae (von Arx \& Müller 1975), while ascostromata are surrounded by a pellicle of superficial mycelium in Chaetothyriaceae (Chomnunti et al. 2012). Phylogenetic analyses have shown them to be unrelated and they were placed in two separate classes, Dothideomycetes and Eurotiomycetes, respectively (Geiser et al. 2006, Schoch et al. 2006, 2009, Chomnunti et al. 2012).

The sooty mould genus Leptoxyphium Speg. was introduced for L. graminum (Pat.) Speg. (三Capnodium graminum Pat.) (Spegazzini 1918). Leptoxyphium is a relatively poorly known genus of sooty moulds in Capnodiaceae (Hyde et al. 2013, Yang et al. 2014). The genus is saprobic on sugary exudates from insects growing on the surface of living leaves. Mycelia are superficial, greybrown to brown, branched, septate, constricted at the septa, forming an irregular network. Leptoxyphium is mainly characterized by the synnemata arising from helically twisting hyphae or ropes of repent hyphae, expanded to become funnel-shaped with a terminal conidiogenous zone (Hughes 1976), and conidia ellipsoidal, hyaline, 1-celled, guttulate (Woronichin 1926, Hughes 1976). In a molecular study (Chomnunti et al. 2011) Leptoxyphium clustered in Capnodiaceae.

Leptoxyphium species were thought to be restricted to the glandular trichomes of leaves. The genus occurs worldwide in form of sooty mould and frequently in pure colonies (Hughes 1976). Interestingly, L. kurandea Crous \& R.G. Shivas described from leaves of Eucalyptus sp. (Myrtaceae), in Queensland, Australia (Crous et al. 2011), was later recovered on a living leaf of Psidium guajava L. (Myrtaceae) in Yunnan Province, China (Yang et al. 2014), and from an insect gut (dusky cotton bug) from Western Ghats, India (Kajale et al. 2015). This genus includes 17 species (Index Fungorum, http://www.indexfungorum.org/names/Names.asp).

Leptoxyphium madagascariense Cheewangkoon \& Crous was described from Madagascar Island, on leaves of Eucalyptus camaldulensis (Cheewangkoon et al. 2009). The purpose of this study is to describe a new record of the genus Leptoxyphium (family Capnodiaceae) isolated from fresh sugarcane juice marketed in Assiut city, Egypt.

\section{Materials \& Methods}

Five juice samples of freshly squeezed sugarcane (Saccharum officinarum L.) were collected from different shops in Assiut city during the period from February to April 2013. The pH of the samples was determined and fungi were isolated onto Dichloran rose bengal chloramphenicol agar, DRBC (King et al. 1979), dichloran 18\% glycerol agar base, DG18 (Hocking \& Pitt 1980) and malt extract yeast extract 50\% glucose agar, MY50G (Pitt \& Hocking 1985).

Filamentous fungi were identified based on their macro- and microscopical features following the keys of Ellis (1971) and Seifert et al. (2011). A Leptoxyphium sp. was thereafter grown on Czapek yeast agar (CYA) and potato sucrose agar (PSA) at $25^{\circ} \mathrm{C}$ in the dark for 14 days. Colony measurements and microscopic features were determined.

For sequencing, the fungus was grown on CYA agar at $25^{\circ} \mathrm{C}$ for 7 days. A small amount of fungal biomass was scraped off, suspended in $100 \mu \mathrm{l}$ of distilled water and boiled at $100{ }^{\circ} \mathrm{C}$ for 15 minutes following the manufacturer's protocol (SolGent Company, Daejeon, South Korea). The samples were directly sent for extraction and sequencing. Fungal DNA was extracted and isolated using SolGent purification beads at this company. Internal transcribed spacer (ITS) sequences of nuclear ribosomal DNA were amplified using the universal primers ITS1 (5'- TCC GTA GGT GAA CCT GCG G -3'), and ITS4 (5'- TCC TCC GCT TAT TGA TAT GC -3'). Amplification was performed using the polymerase chain reaction (PCR) (The GeneAmp® PCR System 9700 thermal cycler, Applied Biosystems, Foster City, California, USA). The PCR reaction mixture was prepared using SolGent EF-Taq. The PCR product was purified with the SolGent PCR Purification Kit-Ultra 
Table 1 Closest matches in GenBank database and sequence similarity as inferred from Blastn searches of ITS sequences with the newly recorded species Leptoxyphium madagascariense strain AUMC 11702 isolated from fresh sugarcane juice in Egypt (accession GenBank number MG323879, length of base pairs $=545$ ).

\begin{tabular}{|c|c|c|c|c|c|c|}
\hline \multicolumn{2}{|c|}{ Genbank match \# ITS } & \multirow{2}{*}{$\begin{array}{l}\text { Sequencing } \\
\text { similarity }(\%)\end{array}$} & \multirow[t]{2}{*}{ gaps } & \multirow[t]{2}{*}{ Species } & \multirow[t]{2}{*}{ Source (leaves) } & \multirow[t]{2}{*}{ Reference } \\
\hline $\begin{array}{l}\text { Culture Collection } \\
\text { code }\end{array}$ & $\begin{array}{l}\text { Accession } \\
\text { no. }\end{array}$ & & & & & \\
\hline CBS $124766^{\mathrm{T}}$ & NR_137731 & $515 / 518(99.42 \%)$ & $1 / 518(0 \%)$ & Leptoxyphium madagascariense & Eucalyptus camaldulensis & Cheewangkoon et al. 2009 \\
\hline CBS $124766^{\mathrm{T}}$ & GQ30-03277 & $515 / 518(99.42 \%)$ & $1 / 518(0 \%)$ & Leptoxyphium madagascariense & Eucalyptus camaldulensis & Cheewangkoon et al. 2009 \\
\hline IFRD $9043^{\mathrm{T}}$ & KF982307 & $518 / 531(97.55 \%)$ & $1 / 531(0 \%)$ & Leptoxyphium glochidion & Glochidion wrightii & Yang et al. 2014 \\
\hline DSM1256 & KX289331 & $530 / 545(97.25 \%)$ & $1 / 545(0 \%)$ & Leptoxyphium fumago & & Kellner et al. 2016 \\
\hline $\mathrm{CPC} 17274^{\mathrm{T}}$ & JF951150 & $527 / 541(97.41 \%)$ & $1 / 541(0 \%)$ & Leptoxyphium kurandae & Eucalyptus $\mathrm{sp}$. & Crous et al. 2011 \\
\hline IFRDCC 2650 & KF982310 & $515 / 529(97.35 \%)$ & $1 / 529(0 \%)$ & Leptoxyphium kurandae & Psidium guajava & Yang et al. 2014 \\
\hline MCC 1085 & KF826942 & $507 / 520(97.50 \%)$ & $1 / 520(0 \%)$ & Leptoxyphium kurandae & Insect gut & Kajale et al. 2015 \\
\hline KUS-F27721 & KM226890 & $492 / 504(97.62 \%)$ & $0 / 504(0 \%)$ & Leptoxyphium kurandae & Hibiscus rosa-sinensi & Park et al. 2015 \\
\hline KUS-F27692 & KP992873 & $491 / 504(97.42 \%)$ & $1 / 504(0 \%)$ & Leptoxyphium kurandae & Hibiscus cannabinus & Choi et al. 2015 \\
\hline OP193 & JN604454 & $451 / 463(97.41 \%)$ & $0 / 463(0 \%)$ & Leptoxyphium kurandae & -- & Taiwan, NCBI website \\
\hline UBC F $23788^{\mathrm{T}}$ & KF263961 & $484 / 553(87.52 \%)$ & $23 / 553(4 \%)$ & Fumiglobus pieridicola & Pieris japonica & Bose et al. 2014 \\
\hline CBS $124785^{\mathrm{T}}$ & NR_132831 & $456 / 514(88.72 \%)$ & $15 / 514(2 \%)$ & Antennariella placitae & Eucalyptus placita & Cheewangkoon et al. 2009 \\
\hline MFLUCC10-0064 & KU358926 & $381 / 409(93.15 \%)$ & $11 / 409(2 \%)$ & Conidiocarpus siamensis & Mangifera $\mathrm{sp}$. & Hongsanan et al. 2015 \\
\hline MFLU15-3564 ${ }^{\mathrm{T}}$ & KU358919 & $378 / 409(92.42 \%)$ & $10 / 409(2 \%)$ & Conidiocarpus plumeriae & Plumeria sp & Hongsanan et al. 2015 \\
\hline MFLU15-3565 & KU358921 & $377 / 410(91.95 \%)$ & $12 / 410(2 \%)$ & Capnodium coffeicola & Coffea sp. & Hongsanan et al. 2015 \\
\hline
\end{tabular}

(SolGent, Daejeon, South Korea) and was sequenced in sense and antisense direction (Moubasher et al. 2017). Contig was created from the sequence data using the CLCBio Main Workbench program. The sequence was further analysed using BLAST from the National Center of Biotechnology Information (NCBI) website. Nucleotide sequence of the target strain together with those retrieved from the GenBank database were subjected to Clustal W analysis using MegAlign software version 5.05 (DNASTAR, Madison, Wisconsin, USA) for the phylogenetic analysis (Thompson et al. 1994). Sequence data were deposited in GenBank and accession numbers are given for them. 


\section{Results and Discussion}

Sugarcane juice showed a mean $\mathrm{pH}$ of 6.45. The fungus (Leptoxyphium madagascariense) was isolated once from one sugarcane sample (out of 5 investigated) on only MY50G, and not on DRBC and DG18 agars. Therefore, this species could be considered a xerotolerant fungus since it was isolated on MY50G and was able to grow on CYA and PSA.
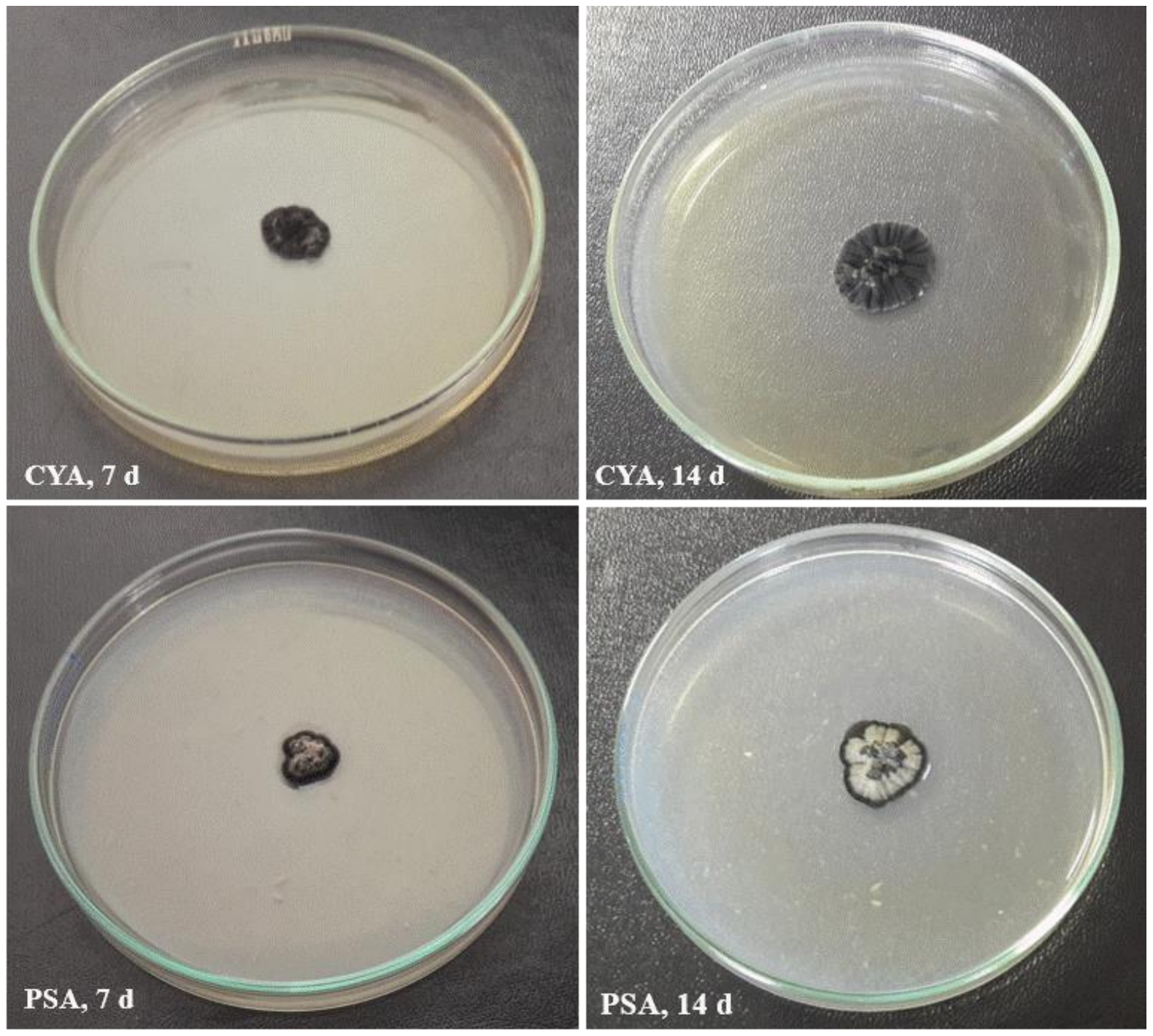

Fig 1 - Leptoxyphium madagascariense AUMC 11702 colony growth on Czapek yeast agar and potato sucrose agar after 7 and 14 days of incubation in the dark at $25^{\circ} \mathrm{C}$.

\section{Leptoxyphium madagascariense Cheewangkoon \& Crous}

Culture characteristics - Colonies were incubated in the dark at $25{ }^{\circ} \mathrm{C}$; on CYA colonies attained $1 \mathrm{~cm}$ diam. after 7 days and $1.8 \mathrm{~cm}$ after 14 days; on PSA $0.9 \mathrm{~cm}$ after 7 days and $1.5 \mathrm{~cm}$ after 14 days. Colonies were slightly raised and obviously folded especially after 14 days, medium to dark brownish grey aerial mycelium. Especially on PSA, numerous, superficial, dark synnemata with whitish conidial masses were produced (Fig 1).

Microscopic characeristics (Fig 2) - Mycelium septate, frequently septate and wider in hyphae around conidiomata, dark grey-brown. Conidiomata determinate synnematal, cylindrical, subulate, superficial, arising from hyphal ropes; stipe composed of unbranched, parallel synnematous hyphae, sometimes with a helical twist, not enclosed in mucilage, occasionally producing 2-3 synnemata on a single hyphal rope; cylindrical part up to $300 \mu \mathrm{m}$ high and $15 \mu \mathrm{m}$ wide, expanding to a funnel-shaped hyphal apex up to $50 \mu \mathrm{m}$ high and $60 \mu \mathrm{m}$ wide, consisting of 
several aggregated, synnematous hyphae that diverge close to the apex; hyphae 3-4.5 $\mu \mathrm{m}$ wide, septate, slightly thick-walled, flaring in apical part, appearing like a terminal hyphal fringe, terminating in rounded apices. Conidiogenous cells integrated, formed from the inner cell surface, intercalary, never terminal, monophialidic, denticle-like, with a truncate apex. Conidia rod-shape, with rounded ends, 1-celled, 4.5-5 $\times 3-3.5 \mu \mathrm{m}$, in a slimy mass at the apex of synnemata, conidia hyaline (not pigmented). Sexual stage not observed.

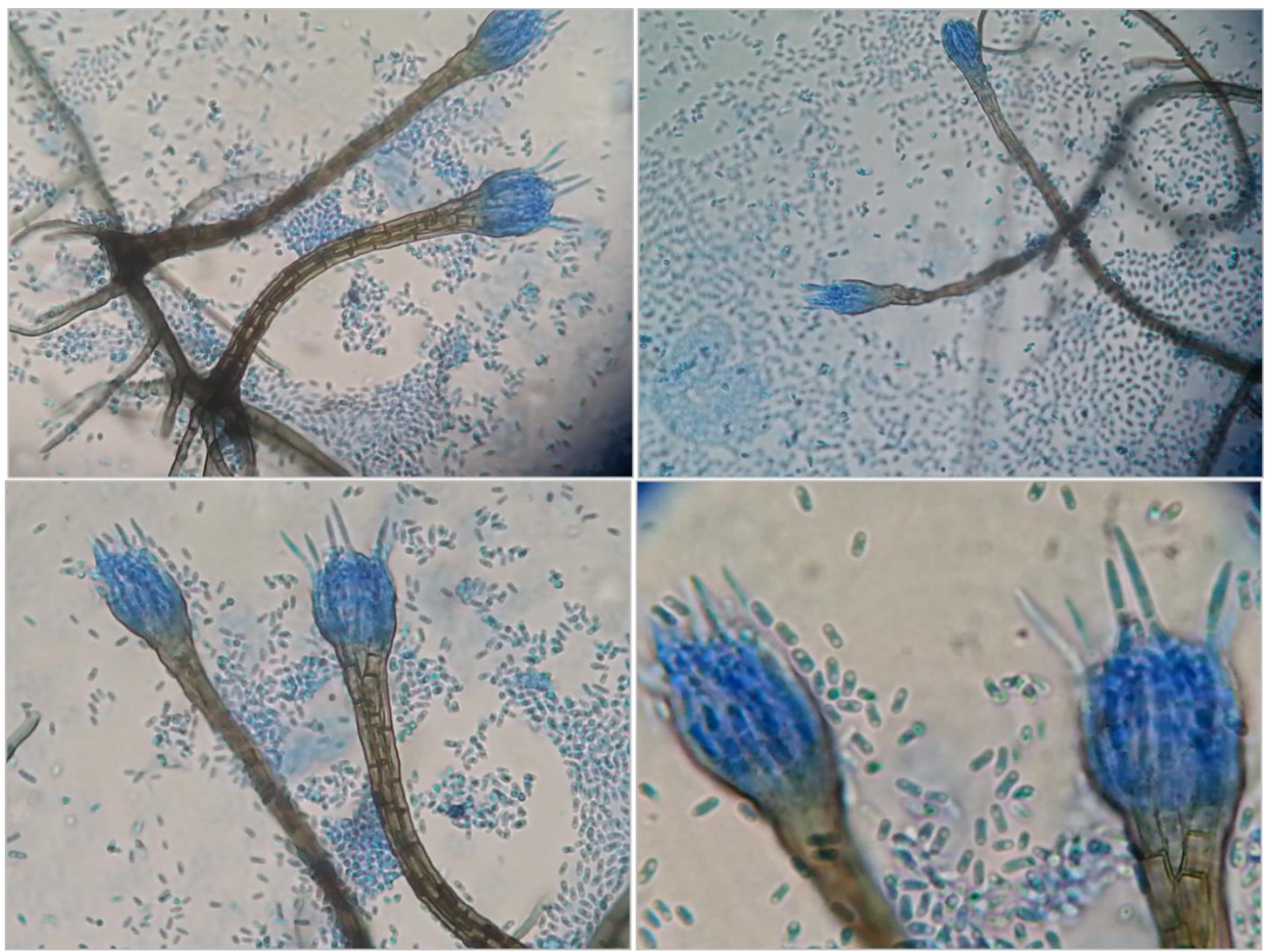

Fig 2 - Leptoxyphium madagascariense AUMC 11702; Synnematous conidiophores, conidiogenous cells and conidia.

Leptoxyphium madagascariense has the typical characterisics of the genus (Hughes 1976). It has elongated synnemata with a stout base, a long, narrow neck and a terminal conidiogenous zone. It produces conidia from monophialidic conidiogenous cells. L. madagascariense can be distinguished from other Leptoxyphium species by its conidial dimensions (Batista \& Ciferri 1963b, Cheewangkoon et al. 2009). Unlike many other Leptoxyphium species, its conidia are not pigmented and remain non-septate during maturation (Batista \& Ciferri 1963b, Hughes 1976).

Molecular identification - Phylogenetically the current strain clusters in the Capnodiales with the type strains of other sooty mould species such as Leptoxyphium madagascariense (99.42\% sequence similarity), L. glochidion (97.55\%), L. fumago (97.25\%), L. kurandae (97.35-97.62\%), Fumiglobus pieridicola (87.52\%), Antennariella placitae (88.72\%), Conidiocarpus siamensis (93.15\%), C. plumeriae (92.42\%), Capnodium coffeicola (91.95\%) with none or only one gap in case of Leptoxyphium species, and from 10 to 23 gaps in species of other genera (Table 1, Fig 3).

In the study of Schoch et al. (2006), L. madagascariense also clustered in the Capnodiales with Microxyphium citri (98\% identical), Leptoxyphium fumago (98\% identical), Capnodium coffeae (96\% identical) and Fumagospora capnodioides (93\% identical). 


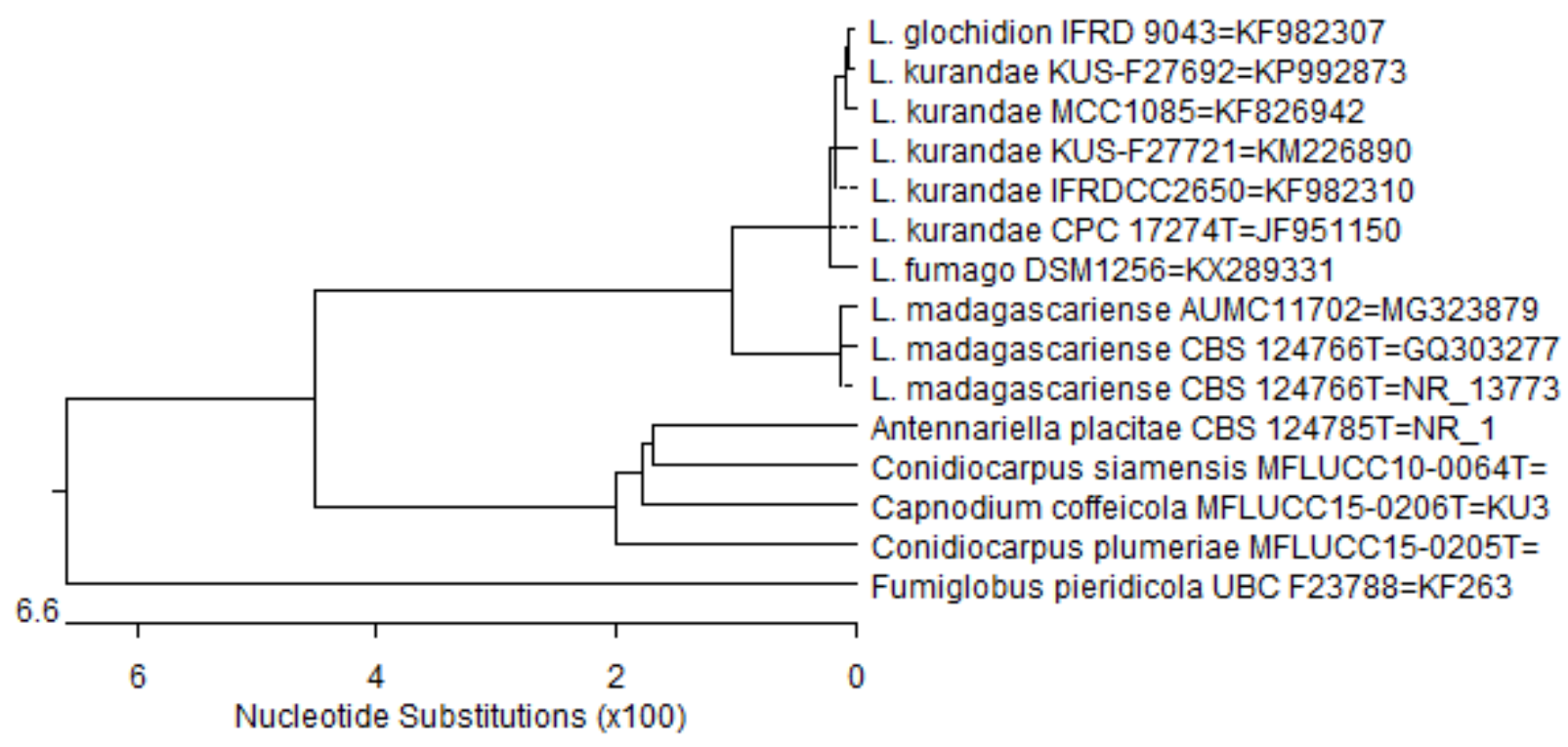

Fig 3 - Phylogenetic relationship of Leptoxyphium madagascariense strain AUMC 11702 with the related strains of Leptoxyphium and other genera.

This species was first collected from Madagascar Island, Morondavo, on leaves of Eucalyptus camaldulensis, in August 2007 and described as a new species (CBS 124766). To the best of our knowledge, this is the second addition worldwide of L. madagascariense after its original description (Cheewangkoon et al. 2009). Its isolation from sugarcane juice may be due to its probable presence on the sugarcane plant. This is also the first report of the genus Leptoxyphium in Egypt.

\section{Acknowledgements}

Assiut University Mycological Centre is greatly acknowledged for the financial support of this work.

\section{References}

Andrews JH. 1992 - Biological control in the phyllosphere. Annual Review of Phytopathology 30, 603-635.

Arx JA von, Müller E. 1975 - A re-evaluation of the bitunicate ascomycetes with keys to families and genera. Studies in Mycology 9, 1-159.

Batista AC, Ciferri R. 1963a - Capnodiales. Capnodiales. Saccardoa 2, 1-296.

Batista AC, Ciferri R. 1963b - The sooty-molds of the family Asbolisiaceae. Quaderno Quaderno. Laboratorio Crittogamico, Istituto Botanico della Università di Pavia 31, 1-229.

Blakeman JP, Fokkema NJ. 1982 - Potential for biological control of plant diseases on the phylloplane. Annual Review Phytopathology 20, 162-192.

Bose T, Reynolds DR, Berbee ML. 2014 - Common, unsightly and until now undescribed: Fumiglobus pieridicola sp. nov., a sooty mold infesting Pieris japonica from western North America. Mycologia 106(4), 746-56. Doi 10.3852/13-288

Cheewangkoon R, Groenewald JZ, Summerell BA, Hyde KD, Toanun C, Crous PW. 2009 Myrtaceae, a cache of fungal biodiversity. Persoonia 23, 55-85. Doi 10.3767/003158509X474752

Choi IY, Kang CH, Lee GH, Park JH, Shin HD. 2015 - Sooty mould disease caused by Leptoxyphium kurandae on Kenaf. Mycobiology 43(3), 347-350. 
Chomnunti P, Schoch CL, Aguirre-Hudson B, Ko-Ko TW, Hongsanan S, Gareth Jones EB, Kodsueb R, Phookamsak R, Chukeatirote E, Bahkali AH, Hyde KD. 2011 - Capnodiaceae. Fungal Diversity 51, 103-134. Doi 10.1007/s13225-011-0145-6

Chomnunti P, Ko-Ko TW, Chukeatirote E, Hyde K D, Cai L, Gareth Jones EB., Kodsueb R, Bahkali AH, Chen H. 2012 - Phylogeny of Chaetothyriaceae in northern Thailand including three new species. Mycologia 104(2), 382-395. Doi 10.3852/11-066

Crous PW, Groenewald JZ, Shivas RG, Edwards J, Seifert KA, Alfenas AC, Alfenas RF, Burgess TI, Carnegie AJ, Hardy GE, Hiscock N, Huberli D, Jung T, Louis-Seize G, Okada G, Pereira OL, Stukely MJ, Wang W, White GP, Young AJ, McTaggart AR, Pascoe IG, Porter IJ, Quaedvlieg W. 2011 - Fungal Planet description sheets: 69-91. Persoonia 26, 108-156.

Ellis MB. 1971 - Dematiaceous Hyphomycetes. Commonwealth Mycological Institute, Kew, 608 pp.

Faull JL, Olejnik I, Ingrouille M, Reynolds D. 2002 - A reassessment of the taxonomy of some tropical sooty moulds. Tropical Mycology 2, 33-40.

Fraser L. 1935 - An investigation of the sooty mould of New South Wales IV. The species of the Eucapnodieae. Proceedings of the Linnean Society of New South Wales 40, 159-178.

Geiser DM, Gueidan C, Miadlikowska J, Lutzoni F, Kauff F, Hofstetter V, Fraker E, Schoch CL, Tibell L, Untereiner WA, Aptroot A. 2006 - Eurotiomycetes: Eurotiomycetidae and Chaetothyriomycetidae. Mycologia 98, 1053-1064.

Hocking AD, Pitt JI. 1980 - Dichloran-glycerol medium for enumeration of xerophilic fungi from low-moisture foods. Applied and Environmental Microbiology 39(3), 488-492.

Höhnel F. von 1910 - Fragmente zur Mykologie (Xi Mitteilung, Nr. 527 bis 573). Sitzungsberichte der Kaiserlichen, Akademie der Wissenschaften in Wien, MathematischNaturwissenschaftliche Klasse, Abteilung 1119, 618-679.

Hongsanan S, Tian Q, Hyde KD, Chomnunti P. 2015 - Two new species of sooty moulds, Capnodium coffeicola and Conidiocarpus plumeriae in Capnodiaceae. Mycosphere 6(6), 814-824. Doi 10.5943/mycosphere/6/6/14

Hughes SJ. 1972 - New Zealand Fungi 17. Pleomorphism in Euantennariaceae and Metacapnodiaceae, two new families of sooty moulds. New Zealand Journal of Botany 10, $225-242$.

Hughes SJ 1976 - Sooty moulds. Mycologia 68, 693-820.

Hughes SJ 2003 - Capnofrasera dendryphioides, a new genus and species of sooty moulds. New Zealand Journal of Botany 41(1), 139-146.

Hyde KD, McKenzie EHC, KoKo TW. 2011 - Towards incorporating anamorphic fungi in a natural classification-checklist and notes for 2010. Mycosphere 2(1), 1-88.

Hyde KD, Jones EBG, Liu JK, Ariyawansa H, Boehm E, Boonmee, S, Braun U, Chomnunti P, Crous PW, Dai DQ, Diederich P, Dissanayake A, Doilom M, Doveri F, Hongsanan S, Jayawardena R, Lawrey JD, Li YM, Liu YX, Lücking R, Monkai J, Muggia L, Nelsen MP, Pang KL, Phookamsak R, Senanayake I, Shearer CA, Suetrong, S, Tanaka K, Thambugala KM, Wijayawardene NN, Wikee S., Wu HX, Zhang Y, Aguirre-Hudson B, Alias SA, Aptroot A, Bahkali AH, Bezerra JL, Bhat DJ, Camporesi E, Chukeatirote E, Gueidan C, Hawksworth DL, Hirayama K, Hoog SD, Kang JC, Knudsen K, Li WJ, Li XH, Liu ZY, Mapook A, McKenzie EHC, Miller AN, Mortimer PE, Phillips AJL, Raja HA, Scheuer C, Schumm F, Taylor JE, Tian Q, Tibpromma S, Wanasinghe DN, Wang Y, Xu JC, Yan JY, Yacharoen S, Zhang M. 2013 - Families of Dothideomycetes. Fungal Diversity 63, 1-313. Doi 10.1007/s13225-013-0263-4

Kajale SC, Sonawane MS, Sharma R, Shouche YS. 2015 - Leptoxyphium kurandae - new record of insect gut associated sooty mould fungus from India. Mycosphere 6(2), 133-138. Doi 10.5943/mycosphere/6/2/2

Kellner H, Pecyna MJ, Buchhaupt M, Ullrich R, Hofrichter M. 2016 - Draft genome sequence of the chloroperoxidase-producing fungus Caldariomyces fumago Woronichin DSM1256. Genome Announcements 4(4), e00774-16. Doi 10.1128/genomeA.00774-16 
King DA, Hocking AD, Pitt JI. 1979 - Dichloran rose Bengal medium for enumeration and isolation of molds from foods. Applied and Environmental Microbiology 37, 959-964.

Kirk PM, Cannon PF, Minter DW, Stalpers JA. 2008 - Dictionary of the Fungi, 10th edn. CABI Bioscience, UK.

Lumbsch HT, Huhndorf SM. 2010 - Outline of Ascomycota - 2009. Fieldiana Life and Earth Sciences 1, 1-60.

Montagne C. 1849 - De Capnodium, novum fungorum genus. Annales des Sciences Naturelles, Botanique, série 3, 11, 233-234.

Moubasher AH, Abdel-Sater MA, Zeinab Soliman 2017 - Incidence and biodiversity of yeasts, dermatophytes and non-dermatophytes in superficial skin infections in Assiut, Egypt. Journal de Mycologie Médicale 27, 166-179. Doi 10.1016/j.mycmed.2017.01.005

Park J, Cho S, Hong S, Choi I, Shin H. 2015 - Sooty mould on Hibiscus rosa-sinensis caused by Leptoxyphium kurandae is associated with extrafloral nectaries. Journal of Phytopathology 163, 1027-1030. Doi 10.1111/jph.12332

Pitt JI, Hocking AD. 1985 - The ecology of fungal food spoilage In: Fungi and food spoilage (Schweigert BS, Stewart GF, eds.), pp. 5-18. Academic Press, Sydney.

Reynolds DR. 1998 - Capnodiaceous sooty mold phylogeny. Canadian Journal of Botany 76, 2125-2130.

Schoch CL, Shoemaker RA, Seifert, KA, Hambleton S, Spatafora JW, Crous PW. 2006 - A multigene phylogeny of the Dothideomycetes using four nuclear loci. Mycologia 98, 10431054.

Schoch CL, Crous PW, Groenewald JZ, Boehm EWA, Burgess TI, de Gruyter J, de Hoog GS, Dixon LJ, Grube M, Gueidan C, Harada Y, Hatakeyama S, Hirayama K, Hosoya T, Huhndorf SM, Hyde KD, Jones EBG, Kohlmeyer J, Kruys Å, Li YM, Lücking R, Lumbsch HT, Marvanová L, Mbatchou JS, McVay AH, Miller AN, Mugambi GK, Muggia L, Nelsen MP, Nelson P, Owensby CA, Phillips AJL, Phongpaichit S, Pointing SB, Pujade-Renaud V, Raja HA, Rivas Plata E, Robbertse B, Ruibal C, Sakayaroj J, Sano T, Selbmann L, Shearer CA, Shirouzu T, Slippers B, Suetrong S, Tanaka K, Volkmann-Kohlmeyer B, Wingfield MJ, Wood AR, Woudenberg JHC, Yonezawa H, Zhang Y, Spatafora JW. 2009 - A class-wide phylogenetic assessment of Dothideomycetes. Studies in Mycology 64, 1-15. Doi 10.3114/sim.2009.64.01

Seifert K, Morgan-Jones G, Gams W, Kendrick B. 2011 - The genera of hyphomycetes. CBSKNAW Fungal Biodiversity Centre, Utrecht, 997 pp.

Spegazzini C. 1918 - Notas Micológicas. Physis (Buenos Aires) 4, 281-295.

Thompson JD, Higgins DG, Gibson TJ. 1994 - CLUSTAL W: improving the sensitivity of progressive multiple sequence alignment through sequence weighting, position-specific gap penalties and weight matrix choice. Nucleic Acids Research 22, 4673-4680. Doi 10.1093/nar/22.22.4673

Woronichin NN. 1926 - Zur Kenntnis der Morphologie und Systematik der Russtaupilze Tran skaukasiens. Annales Mycologici 24(3/4), 231-264.

Yang H, Ariyawansa HA, Wu H-X Hyde KD. 2014 - The genus Leptoxyphium (Capnodiaceae) from China. Phytotaxa 176(1), 174-183. Doi 10.11646/phytotaxa.176.1.17 